\title{
Perinatal serotonergic activity: A decisive factor in the control of food intake
}

\author{
Atividade serotoninérgica perinatal: um fator \\ decisivo para o controle da ingestão alimentar
}

The serotoninergic system controls key events related to proper nervous system development. The neurotransmitter serotonin and the serotonin transporter are critical for this control. Availability of these components is minutely regulated during the development period, and the environment may affect their action on the nervous system. Environmental factors such as undernutrition and selective serotonin reuptake inhibitors may increase the availability of serotonin in the synaptic cleft and change its anorectic action. The physiological responses promoted by serotonin on intake control decrease when requested by acute stimuli or stress, demonstrating that animals or individuals develop adaptations in response to the environmental insults they experience during the development period. Diseases, such as anxiety and obesity, appear to be associated with the body's response to stress or stimulus, and require greater serotonergic system action. These findings demonstrate the importance of the level of serotonin in the perinatal period to the development of molecular and morphological aspects of food intake control, and its decisive role in understanding the possible environmental factors that cause diseases in adulthood.

Keywords: Eating. Malnutrition. Serotonin. Serotonin uptake inhibitors.

\section{R E S U M O}

O sistema serotoninérgico apresenta funções no controle de eventos biológicos fundamentais para o desenvolvimento adequado do sistema nervoso. A serotonina e o transportador de serotonina são indispensáveis

\footnotetext{
1 Universidade Federal de Pernambuco, Centro de Ciências da Saúde, Departamento de Nutrição. Av. Professor Moraes Rêgo, 1235, Prédio de Nutrição, Cidade Universitária, 50670-901, Recife, PE, Brasil. Correspondência para/Correspondence to: R MANHÃES DE CASTRO. E-mail: <raulmanhaesdecastro@gmail.com>.

2 Universidade Federal de Pernambuco, Centro de Ciências da Saúde, Departamento de Anatomia. Recife, PE, Brasil. encefálico de animais jovens submetidos à fluoxetina neonatal”. Universidade Federal Pernambuco; 2017.
} 
para esta função de controle. A disponibilidade destes componentes é precisamente regulada durante o período de desenvolvimento, e podem sofrer interferências provindas do ambiente alterando sua ação sobre o sistema nervoso. A desnutrição, a inibição da recaptação da serotonina a partir de fármacos e mudanças na expressão de gênica do transportador de serotonina na gestação e lactação podem induzir o aumento de serotonina alterando sua ação anorexígena. As respostas fisiológicas desempenhadas pela serotonina no controle da ingestão exibem uma resistência quando requisitadas por estímulos ou estresses agudos, demonstrando que os animais ou indivíduos desenvolvem adaptações de acordo com as agressões ambientais sofridas no período de desenvolvimento. Patologias como, ansiedade e obesidade, parecem estar associadas à resposta do organismo a um estresse ou estímulo, necessitando de uma maior ação do sistema serotoninérgico. Estes achados demonstram a importância do conteúdo da serotonina no período perinatal ao desenvolvimento de aspectos moleculares e morfológicos do controle da ingestão alimentar, e sua função determinante para a compreensão das possíveis influências ambientais causadoras de patologias na vida adulta.

Palavras-chave: Ingestão de alimentos. Desnutrição. Serotonina. Inibidores da captação de serotonina.

\section{NTRODUCTIO N}

The serotonergic system is essential for the proper development of the nervous system. Serotonin or 5-Hydroxytryptamine (5-HT) and Serotonin Transporter (SERT) are essential for nervous system ontogenesis and maturation [1]. Environmental factors, such as malnutrition, selective serotonin reuptake inhibition, and changes in the expression of the serotonin transporter gene during the early stages of development may increase central serotonin availability, delay in satiety the trigger associated with hyperphagia, and reduce its anorexigenic effects in adult organisms [2-4]. However, despite the numerous studies conducted in recent years, the origin of the physiological and molecular mechanisms controlled by the serotonergic system has not been totally clarified. This review article focuses on the influence of serotonergic activity during the development period on food intake control.

\section{Critical development period and phenotypic plasticity}

Phenotypic plasticity is established to develop a central function on the etiology of chronic-degenerative diseases associated with the hypothesis of the development-related origin of health and disease. The risk of developing chronic diseases is closely related to the environment in which an individual developed and his lifestyle in adulthood. Phenotypic plasticity is considered an adaptive process that allows the refinement of development patterns and mechanisms according to the surrounding environment. From the adaptive perspective, an individual will be benefitted by his ability to adapt to the environment [5].

Pieces of evidence of these adaptations in humans were demonstrated in 1970 by Ravelli et al. [6]. The Dutch Famine consisted of a period of food scarcity experienced by pregnant women during World War II (19441945). In adulthood, approximately 300,000 men exhibited changes in body composition, depending on the time in which they, as fetuses, had been exposed to maternal malnutrition. If malnutrition occurred in the last trimester of pregnancy, these individuals would have a low incidence of obesity. However, if it occurred in the first trimester, they would have a higher incidence of obesity [6].

In the 1960s Neel [7] described the 'thrifty genotype hypothesis', proposing that some populations were more susceptible to insulin resistance because of its possible relationship with environmental or genetic factors. The body's adaptation could benefit individuals who were exposed to food scarcity [7]. Some hypotheses had been explored by Neel [7], leading to a greater understanding of the importance of the gestation and breastfeeding periods to disease susceptibility in adult life. Certain subjects, such as metabolic programming and critical 
development period, related to this knowledge resulted in a greater understanding of some diseases, such as diabetes and obesity.

The critical period represents a development window that cannot be inverted or repeated later on. Faster organization processes are more easily modified or interrupted [8]. Unlike the maintenance period, physiological processes during development do not have a uniform rate of emergence and duration. All processes exhibit critical periods whose importance and duration will depend on their variation rates. In the embryonic brain, many physiological events accelerate, slow down, or end their activities in a short period of time. The concept of vulnerability implies that the organization process is subject to perturbations that influence their rate of emergence or duration [9].

The nervous system development period consists of biological events, such as cell proliferation and differentiation, neuron migration, myelinization, and synaptogenesis, which act on the organization and specialization of many brain structures [9]. During this period, they are extremely sensitive to environmental stimuli [8]. In humans the critical period starts in the prenatal phase, especially the last trimester of pregnancy, and continues until age five years. In rodents this phase lasts three weeks, starting at birth, the breastfeeding period [9].

Epidemiological studies have found a correlation between the critical development period and the onset of metabolic diseases in adulthood. One of the first hypotheses suggested by Hales \& Barker [10], the thrifty phenotype hypothesis, proposes that stimuli or insults that occur during pregnancy, the perinatal period, and breastfeeding can promote physiological and metabolic adaptations. These adaptations may increase the provision of nutrients for the development of vital organs, such as the brain, in detriment of other organs. In the short run, the body would be able to adapt to the environment in order to survive. However, in the long run, these adaptations would increase the body's susceptibility to disease. The studies on the thrifty phenotype hypothesis associate poor fetal and infant growth with higher susceptibility to low glucose tolerance and the metabolic syndrome in adulthood. A key issue for the discussion of this hypothesis is the proportion in which subjacent mechanisms are genetic or environmental [10].

During the study of the thrifty genotype and metabolic programming hypotheses, a new theoretical model is proposed by Wells [5], associating growth from childhood to adulthood to the risk of cardiovascular diseases in adulthood. In this hypothesis, birth weight is considered a 'metabolic capacity' index in which organ structure and function during intrauterine life and childhood promote homeostasis maintenance. According to this model, body and fat tissue growth are predictors of higher metabolic load just like low birth weight is a predictor of low metabolic capacity [5].

The theoretical models are inserted in the fetal origins of adult disease or phenotypic plasticity hypotheses. According to Gluckman et al. [11], genetic predisposition associated with environmental stimuli during development influences adaptive responses to the environment and increases susceptibility to disease in adulthood. Thus, phenotypic plasticity represents organisms' responses to different environmental conditions that generate a series of distinct phenotypes (morphological or physiological states) potentially expressed by a genotype [11]. To adjust cell processes according to environmental changes, epigenetic programming allows hereditary and reversible change of gene expression without changing the DNA sequence [12]. Epigenetic regulation may "program" genetic information and cell fate, and determine body, including brain, functionality. These mechanisms allow adaptive responses to environmental changes and optimize the chances of survival and reproduction [12]. In mammals, the signs that induce development plasticity are mediated during the fetal and neonatal period [12]. The 
induction of phenotypic changes in offspring promoted by the mother may involve changes in the epigenome secondary to changes in DNA methyltransferase activity and histone structures [12]. In this review we describe the environmental influences that are associated with serotonin level in the central nervous system, such as malnutrition, selective serotonin reuptake inhibition, and change in serotonin transport gene expression during the development period. These influences promote structural, physiological, and behavioral changes, especially in food intake control.

\section{Serotoninergic system and development}

Serotonin or 5-hydroxytryptamine is a monoamine widely distributed in the central nervous system. During development, it acts as a cell signaling agent, neuromodulator, hormone, and neurotransmitter, and its function may vary depending on the region in which it is located and the body's development and maturation phase. This molecule influences the induction of neurogenesis, neuronal differentiation, and synaptogenesis, and allows self-regulation of serotonergic neurons and development of target tissues [13]. Control of these biological events is essential for the proper development of the central nervous system. The first studies were able to identify the central serotonin level, morphology of its neurons, and components of this neurotransmission system, the enzyme Tryptophan Hydroxylase (TPH), the Serotonin Transporter (SERT), and the presence of serotonin [1,14-16].

In the human brain, 5-HT neurons first appear in the brainstem in the fifth week of intrauterine life [14]. Brain levels of 5-HT increase during intrauterine life until age two years, stabilize for a few years, then peaks at age five years [17]. In rodents serotonergic neurons appear between days 10 and 12 of intrauterine life, with serotonin synthesis detected one day after their appearance; they complete their maturation at the end of the critical period $[1,15]$. After their appearance, serotonergic neurons emerge from the raphe nuclei in order to modulate the development and maturation of neuronal circuits in the hypothalamus, nucleus of the solitary tract, and cerebral cortex $[15,18,19]$.

Since serotonin is hydrophilic and does not cross the blood-brain barrier, it must be synthesized in the brain from the essential amino acid tryptophan. This amino acid must be present in the diet as the body cannot synthesize it [20]. Central serotonin synthesis occurs mainly in serotoninergic neurons of the dorsal raphe nucleus. Plasma tryptophan is either free or bound to albumin. Once it enters the neuron, tryptophan is hydrolyzed to 5-Hydroxytryptophan (5-HTP) by the enzyme $\mathrm{TPH}-2$ present in the central nervous system [16]. Next, 5-HTP is decarboxylated by the enzyme aromatic L-amino acid decarboxylase to form serotonin.

After its synthesis in raphe neurons, serotonin is stored in vesicles present in presynaptic neurons. When free in the synaptic gap, 5-HT can act in its receptors, but after this interaction, its action ends. One of the degradation pathways of serotonin is performed by the enzymes monoamine oxidase $A$ and $B$, breaking down serotonin into 5-hydroxyindoleacetic acid [21]. A second mechanism of serotonin degradation regards its reuptake by its transporter, located in the pre-synaptic membrane [22]. SERT is the main agent responsible for the regulation of 5-HT levels in the synaptic gap. The function of this cell membrane protein is to reuptake $5-\mathrm{HT}$ that has not been broken down by monoamine oxidase in the synaptic gap and transfer it to the inside of the pre-synaptic neurons [22]. Active removal increases the speed in which the levels of neurotransmitter in the synaptic gap decrease, restricting the effects of $5-\mathrm{HT}$ to smaller areas, and recycles some of the neurotransmitter relased in the synapse for later use [22]. By changing its conformation, SERT moves one 
or more serotonin molecules per cycle, unlike transmembrane channels, which remain open or closed. This allows molecules to exit the lipid-bilayered membrane.

Serotonin levels during nervous system development are minutely regulated, allowing early detection of intense serotonergic immunoreactivity [1]. During gestation, the placenta can synthesize and transport serotonin using a complex system of maternal conversion of tryptophan, the amino acid precursor of serotonin, into serotonin, releasing it in the fetal circulation [23]. A prenatal increase in tryptophan availability may prevent hyperinnervation of serotonergic neurons. This increase delays the development of serotonergic axons and reduces the synthesis of 5-HT [24]. Serotonergic innervation goes through hyperinnervation phases or temporary expression of some serotonergic receptors, which may be decisive for the participation of serotonin on the development and plasticity of the central nervous system. In mammals, the final density and distribution of serotonergic terminals are shaped during the postnatal maturation of the central nervous system [1]. Excess 5-HT during embryogenesis in SERT knockout animals reversibly reduces the radial migration speed of cortical pyramidal neurons, affecting the arborization of these neural circuits. The receptor $5-\mathrm{HT} 6$, expressed in pyramidal neuron progenitors when activated, replicates the effects of serotonergic stimulation [19]. These findings support the hypothesis that serotonergic homeostasis deregulation during development may affect the formation of the neocortical circuit and contribute to increase susceptibility to psychiatric disorders [19]. However, initiation of growth and innervation of serotonergic neurons may be an important inductor of structural and behavioral abnormalities.

Serotonergic neurons are widely distributed in rodent brain. Its projections originate at the raphe nuclei, located along the brainstem midline, and consist of numerous and distinctive groups of neurons that organize themselves, sending out ascending and descending projections $[1,25]$. Two groups of serotonergic neurons seem to have distinct maturation pattern and migration. The rostral group, formed by the dorsal, caudal linear, and median raphe nuclei send predominantly rostral projections to the thalamus and hypothalamus. On the other hand, the caudal group formed by the nuclei raphe pallidus, raphe obscurus, and raphe magnus projects more caudally and ventrally to innervate the spinal cord and cerebellum $[1,25]$. Because of its widespread distribution in the central nervous system, serotonin influences many mammalian physiological spheres, from cardiovascular, respiratory, gastrointestinal, pain sensitivity, and thermogenic regulation to appetite, circadian rhythm, eating and sexual behavior, humor, locomotion, sleep, learning, and memory [26].

The development of the serotonergic properties or raphe neurons, such as serotonin synthesis, reuptake, and storage depend on a positive feedback system based on the presence of small amounts of 5-HT in order to initiate its own synthesis and stimulate the development of these properties, even in neurons that normally do not produce 5-HT [27]. This mechanism may be responsible for the quick development of serotonergic neurons and for the transitory presence of 5-HT in some neurons during development [15]. The synthesis of 5-HT from tryptophan increases in response to the frequency of electrical stimulation of the serotonergic cell body $[16,22]$. Short-term requirements for higher 5 -HT synthesis may occur by changing the kinetic properties of TPH without the need to increase TPH level [28]. Serotonergic neurotransmission balance may present an increase in its metabolic processes in order to adapt to the demands made by environmental stimuli and aggressions.

\section{Serotonin and food intake}

Diet may be primarily considered a regulatory behavior whose function is to provide 
energy to the body tissues, a critical process for survival [29]. The Solitary Tract Nucleus (STN) and the hypothalamus are considered the centers for detecting and responding to signs of hunger and satiety. The first central nervous system region to receive visceral sensory information from the oral cavity and peripheral regions is the STN, especially from the vagus nerve. The STN controls the beginning and end of digestion, and meal size [29]. The information that arrives at this nucleus is processed and transmitted to other brain areas, such as the hypothalamus and parabrachial complex, through direct or reciprocal connections [30-32]. The afferents received by the lateral parabrachial nucleus from the STN may be involved in visceral sensory responses [32].These neuronal projections are an important pathway to suppress food intake. Stimulation of lateral parabrachial nucleus fibers reduces food intake [32]. Moreover, the STN sends the visceral information it receives to hypothalamic centers of homeostatic control, and receives descendent projections from the lateral hypothalamus and Paraventricular Nucleus [30,31]. The arcuate, ventromedial, dorsomedial, and paraventricular nuclei, and the lateral hypothalamus area are associated energy balance regulation [18]. The hypothalamus receives vagal afferents from the gastrointestinal tract, pancreas, liver, and adipose tissue, and integrates the information received from these organs and tissues with central information on hunger and satiety [18].

Serotonin is intimately related to food intake and seems to have an inverse relationship with energy intake as it reduces food intake by stimulating satiety in rats [33]. In the hypothalamus high serotonin levels promote satiety and low levels promote food intake [33]. The serotonergic neurons from the raphe nuclei send projections to the hypothalamus in order to control aspects of food intake, such as macronutrient selection and meal size, and energy balance for maintaining body weight $[18,33]$. The STN and the hypothalamus receive Neuronal populations that express neuropeptide
Y (NPY), Cocaine- and Amphetamine-Regulated Transcript (CART), Agouti-Related Protein (AgRP), and Proopiomelanocortin (POMC). The POMC neurons of the STN are activated by vagal afferents and satietogenic signals that limit food intake [32]. Stimulation of the AgRP and NYP neurons encourages food intake and reduces energy expenditure, while stimulation of the POMC and CART neurons reduces food intake and increases energy expenditure [18]. These responses may be mediated by serotonergic receptors [34]. Divided into seven classes (5HT, to $5 \mathrm{HT}_{7}$ ) and 14 subtypes, the $5-\mathrm{HT}_{1 \mathrm{~A}^{\prime}} 5-\mathrm{HT}_{1 \mathrm{~B}^{\prime}}$ and $5-\mathrm{HT}_{2 \mathrm{C}}$ receptors present serotonergic action on food intake $[28,34,35]$. The central use of $8-\mathrm{OH}-\mathrm{DPAT}, 5-\mathrm{HT}_{1 \mathrm{~A}}$ agonist, induced hyperphagia [35]. The $5 \mathrm{HT}_{1 \mathrm{~B}}$ receptors expressed in serotonergic neurons act as self-receptors, inhibiting adenylyl cyclase, hyperpolarizing the neuron and reducing serotonin release [34]. The $5 \mathrm{HT}_{2 \mathrm{C}}$ receptors seem to modulate meal size and duration of food intake behavior [33]. In the arcuate nucleus of the hypothalamus, 5-HT hyperpolarizes and inhibits AgRP neurons, promoting inhibition of the POMC cells through $5-\mathrm{HT}_{1 \mathrm{~B}}$ receptors, and acts on $5-\mathrm{HT}_{2 \mathrm{C}}$, activating POMC neurons modulating food intake [34]. The rhythm of serotonergic activity in relation to food intake is associated with the transition of the day/night light cycles, as reflected by temporal changes in response to the $5-\mathrm{HT}_{1 \mathrm{~B}}$ receptor in the medial hypothalamus and in the release and use of endogenous 5-HT. Smaller serotonergic activity begins at the start of the activation of the food intake period, exactly on the transition of the light/dark light cycles [36]. At the beginning of the dark cycle, the active period for food intake in rodents, serotonergic stimulation more effectively suppresses food intake and particularly, carbohydrate intake [36]. The genes responsible for regulating serotonergic action, such as the gene slc6a14, which codifies sodium- and chloride-dependent amino acid transporters, and the gene 5-htr ${ }_{2 c^{\prime}}$ which codifies the $5-\mathrm{HT}_{2 \mathrm{C}}$ receptor, may be determinants of children's food intake control 
and nutritional status. The gene slc6a14 regulates tryptophan availability for serotonin synthesis. Children aged 7 to 8 years with slc6a14 (rs2312054) and slc6a14 (rs12391221) polymorphisms in leukocytes have higher food intake [4]. This finding may indicate a possible association between these polymorphisms in adulthood obesity.

The interaction between nutrition in the critical development period, serotonin action, and repercussions in adulthood has been documented by many researchers [2,9,37-40]. Perinatal malnutrition is one of the environmental factors responsible for structural and functional changes in central nervous system development, such as fewer neurons, and changes in neuronal shape and neurotransmitter levels $[2,41]$. The serotonergic system is greatly influenced by perinatal malnutrition [2]. The brain levels of serotonin increase during the postnatal period and adulthood of animals submitted to perinatal protein malnutrition. These changes may be related to higher levels of tryptophan in the brain and to the activity of 5-TPH, confirming the need of finely controlling $5-\mathrm{HT}$ availability in the brain during the critical development period [2]. These changes may stem from response changes in serotonin neurotransmission.

Perinatal protein malnutrition seems to reduce weight gain and food intake in rats [37-40]. These animals gain less weight as they grow and have lower weight in adulthood. Despite this lower body weight, perinatal protein malnutrition increases food intake $[37,38]$. In the neonatal period, protein malnutrition reduced masticatory efficiency, weakening and delaying masticatory muscle maturation and the associated neuronal circuit [39]. A functional change associated with neonatal malnutrition and food intake seems to decrease the inhibitory effects of tryptophan on food intake in adulthood [40]. This resistance to the inhibitory effects of serotonin has also been observed in malnourished animals in gestation and lactation when submitted to acute fenfluramine administration [37]. Serotonin control on food intake seems to fail when protein intake during the critical development period is sufficiently low.

Understanding the regulation of gene expression, such as the mechanism of induction of different phenotypes promoted by maternal diet during the critical period, allows a better understanding of the relationship between serotonin and control of food intake. The absence of serotonin reuptake mechanism in SERT knockout animals increases the extracellular levels of serotonin [42]. Despite the hypophagic characteristic of 5-HT, these animals have an obese phenotype in adulthood [43]. The mechanism associated with this obese phenotype in these animals has yet to be completely understood. These obese rodents are not hyperphagic, but they present changes in their exploratory behavior, such as low physical activity in their cages [43]. This obese phenotype may be reverted in animals when SERT is upregulated, demonstrating a possible consequence of low extracellular levels of brain serotonin secondary to higher SERT expression. Animals with upregulated SERT have low body weight and no changes in food intake $[44,45]$.

Some pharmaceuticals, such as fenfluramine, can increase $5-\mathrm{HT}$ levels by stimulating vesicular release and inhibiting reuptake, which promotes hypophagia, smaller meals, and higher intervals between meals in rodents [37]. The function of fenfluramine is to suppress food intake and facilitate weight loss by increasing metabolic rate [37]. Pharmacological or genetic SERT inhibition also evidences the inhibition of food intake. Higher serotonin levels promoted by selective serotonin reuptake inhibitors result in lower food intake. Fluoxetine increases serotonin in the hypothalamus and its hypophagic action [33].

Exposure to selective serotonin reuptake inhibitors during lactation reduces body weight and food intake $[3,46]$. The use of citalopram during lactation decreased growth and delayed the maturation of rodents' physical 
characteristics [47]. The body weight of rodents exposed to fluoxetine was $22 \%$ lower at age 21 days [46]. The low body weight phenotype persisted to adulthood in neonatal animals exposed to fluoxetine [3]. In rodents, fluoxetine increases serotonin, stimulating satiety, which reduces food intake and body weight [33]. The development of the appetite regulation pathways in the hypothalamus occur predominantly after birth [48]. These pieces of evidence indicate that the postnatal period is important for food intake programming in rodents.

Physiological responses present a resisted response to acute stimuli or stress, demonstrating that these organisms develop adaptations according to the manipulations they experience during development periods or critical periods, which cannot be resolved depending on the demands of a new environment. The development of anxiety, obesity, and other diseases seems to be associated with an organism's need to respond to a stress or stimulus that requires higher action of its control systems, such as the serotonergic system. These findings show the importance of perinatal serotonin in the development of molecular and morphological components in food intake control, and its determinant function for understanding the possible environmental influences that cause diseases in adulthood.

\section{ACKNOWLEDGMENTS}

We thank our research group mates for their collaboration.

\section{CONTRIBUTORS}

All authors helped to idealize and discuss the subjects, and to write and edit the manuscript.

\section{RE FER E N CES}

1. Lidov $\mathrm{H}$, Molliver M. An immunohistochemical study of serotonin neuron development in the rat: Ascending pathways and terminal fields. Brain
Res Bull. 1982;8(4):389-430. https://doi.org/10. 1016/0361-9230(82)90077-6

2. Manjarrez G, Chagoya G, Hernández R J. Early nutritional changes modify the kinetics and phosphorylation capacity of tryptophan-5hydroxylase. Int J Dev Neurosci. 1994;12(8):695-702. https://doi.org/10.1016/0736-5748(94)90 049-3

3. Galindo LCM, Barros MLD, Pinheiro IL, Santana RVC, Matos RJB, Leandro CG, et al. Neonatal serotonin reuptake inhibition reduces hypercaloric diet effects on fat mass and hypothalamic gene expression in adult rats. Int J Dev Neurosci. 2015;46:76-81. https://doi.org/10.1016/j.ijdevneu. 2015.07.004

4. Miranda R, Vetter S, Genro J, Campagnolo P, Mattevi V, Vitolo M, et al. SLC6A14 and 5-HTR2C polymorphisms are associated with food intake and nutritional status in children. Clin Biochem. 2015;48(18):1277-82. https://doi.org/10.1016/j. clinbiochem.2015.07.003

5. Wells J. Adaptive variability in the duration of critical windows of plasticity: Implications for the programming of obesity. Evol Med Public Health. 2014;2014(1):109-21. https://doi.org/10.1093/ emph/eou019

6. Ravelli G, Stein Z, Susser M. Obesity in young men after famine exposure in utero and early infancy. N Engl J Med. 1976;295(7):349-53. https://doi. org/10.1056/NEJM197608122950701

7. Neel JV. Diabetes Mellitus: A "thrifty" genotype rendered detrimental by "Progress"? Am J Hum Genet. 1962;14(4):353-62.

8. Dobbing J. Undernutrition and the developing brain: The relevance of animal models to the human problem. Am J Dis Child. 1970;120(5):411.

9. Morgane $\mathrm{P}$, Miller M, Kemper T, Stern W, Forbes $W$, Hall R, et al. The effects of protein malnutrition on the developing central nervous system in the rat. Neuro Sci Bio Behav Rev. 1978;2(3):137-230. https://doi.org/10.1016/0149-7634(78)90059-3

10. Hales C, Barker DJ. The thrifty phenotype hypothesis. Br Med Bull. 2001;60(1):5-20. https:// doi.org/10.1093/bmb/60.1.5

11. Gluckman P, Hanson M, Low F. The role of developmental plasticity and epigenetics in human health. Birth Defects Res C Embryo Today. 2011;93(1):12-18. https://doi.org/10.1002/ bdrc.20198

12. Skinner MK, Manikkam M, Guerrero-Bosagna C. Epigenetic transgenerational actions of endocrine disruptors. Reprod Toxicol. 2011;31(5727):337-43. https://doi.org/10.1016/j.reprotox.2010.10.012

13. Whitaker-Azmitia PM, Druse M, Walker P, Lauder JM. Serotonin as a developmental signal. Behav Brain Res. 1996;(73):19-29. 
14. Sundstrom E, Kolare S, Souverbie F, Samuelsson $E B$, Pschera $H$, Lunell NO, et al. Neurochemical differentiation of human bulbospinal monoaminergic neurons during the first trimester. Brain Res Dev Brain Res. 1993;(75):1-12

15. Gaspar, P, Cases O, Maroteaux, I. The developmental role of serotonin: News from mouse molecular genetics. Nat Rev Neuro Sci. 2003;4(12):1002-12. https://doi.org/10.1038/nrn1256

16. Walther D, Peter JU, Bashammakh S, Hörtnagl H, Voits M, Fink $\mathrm{H}$, et al. Synthesis of Serotonin by a Second Tryptophan Hydroxylase Isoform. Science. 2003;299(5603):76. https://doi.org/10.1126/science. 1078197

17. Chugani DC, Muzik O, Behen M, Rothermel R, Janisse JJ, Lee J, et al. Developmental changes in brain serotonin synthesis capacity in autistic and nonautistic children. Ann Neurol. 1999;45(3):28795.

18. Morton G, Cummings D, Baskin D, Barsh G, Schwartz M. Central nervous system control of food intake and body weight. Nature. 2006;443(7109):289-95. https://doi.org/10.1038/ nature05026

19. Riccio O, Jacobshagen M, Golding B, Vutskits L, Jabaudon D, Hornung, et al. Excess of serotonin affects neocortical pyramidal neuron migration. Transl Psychiatry. 2011;1(10):e47. https://doi.org/10. 1038/tp.2011.49

20. Azmitia EC. Evolution of serotonin: Sunlight to suicide. In: Muller CP, Jacobs BL, editors. London: Handbook of the behavioral neurobiology of serotonin. London: Academic Press; 2010. p.3-22.

21. Sablin S, Yankovskaya V, Bernard S, Cronin C, Singer T. Isolation and characterization of an evolutionary precursor of human monoamine oxidases A and B. Eur J Biochem. 1998;253(1):270-9.

22. Sghendo L, Mifsud J. Understanding the molecular pharmacology of the serotonergic system: Using fluoxetine as a model. J Pharm Pharmacol. 2012;64(3):317-25. https://doi.org/10.1111/j.20 42-7158.2011.01384.x

23. Bonnin A, Levitt P. Fetal, maternal and placental sources of serotonin and new implications for developmental programming of the brain. Neuroscience. 2011;197:1-7. https://doi.org/10. 1016/j.neuroscience.2011.10.005

24. Huether G, Thornke F, Adler L. Administration of tryptophan-enriched diets to pregnant rats retards the development of the serotonergic system in their offspring. Dev Brain Res. 1992;68(2):175-81.

25. Wallace JA, Lauder JM. Development of the serotonergic system in the rat embryo: An immunocytochemical study. Brain Res Bull. 1983;10(4):459-79.
26. Sodhi MS, Sanders-Bush E. Serotonin and brain development. Int Rev Neurobiol. 2004;(59):111-74. https://doi.org/10.1016/S0074-7742(04)59006-2

27. De Vitry F, Hamon M, Catelon J, Dubois M, Thibault J. Serotonin initiates and auto-amplifies its own synthesis during mouse central nervous system development. Proc Natl Acad Sci. 1986;(22):8629-33.

28. Hensler JG. Serotonin. In: Siegel GJ, Albers RW, Scott B, Price DD, editors. Basic neurochemistry: Molecular, cellular and medical aspects. San Diego: Academic Press; 2006. p.227-48.

29. Schwartz GJ. Integrative capacity of the caudal brainstem in the control of food intake. Philos Trans R Soc Lond B Biol Sci. 2006;361(1471):1275-80. https://doi.org/10.1098/rstb.2006.1862

30. Jiang C, Fogel R, Zhang X. Lateral hypothalamus modulates gut-sensitive neurons in the dorsal vagal complex. Brain Res. 2003;980(1):31-47. https://doi.org/10.1016/S0006-8993(3)02844-0

31. Zhang X, Cui J, Tan Z, Jiang C, Fogel R. The central nucleus of the amygdala modulates gutrelated neurons in the dorsal vagal complex in rats. J Physiol. 2003;553(Pt.3):1005-18. https://doi.org/10.1 113/jphysiol.2003.045906

32. Rinaman L. Ascending projections from the caudal visceral nucleus of the solitary tract to brain regions involved in food intake and energy expenditure. Brain Res. 2010;1350:18-34. https:// doi.org/10.1016/j.brainres.2010.03.059

33. Halford JC, Harrold JA, Lawton CL, Blundell JE. Serotonin (5-HT) drugs: Effects on appetite expression and use for the treatment of obesity. Curr Drug Targets. 2005;6(2):201-13. https://doi. org/10.2174/1389450053174550

34. Heisler L, Jobst E, Sutton G, Zhou L, Borok E, Thornton-Jones $Z$, et al. Serotonin reciprocally regulates melanocortin neurons to modulate food intake. Neuron. 2006;51(2):239-49. https://doi. org/10.1016/j.neuron.2006.06.004

35. Bendotti C, Samanin R. 8-Hydroxy-2-(di-npropylamino) tetralin (8-OH-DPAT) elicits eating in free-feeding rats by acting on central serotonin neurons. Eur J Pharmacol. 1986;121(1):147-50.

36. Weiss GF, Rogacki N, Fueg A, Buchen D, Leibowitz SF. Impact of hypothalamic d-norfenfluramine and peripheral d-fenfluramine injection on macronutrient intake in the rat. Brain Res Bull. 1990;25(6):849-59.

37. Lopes de Souza S, Orozco-Solis R, Grit I, Manhães de Castro R, Bolaños-Jiménez F. Perinatal protein restriction reduces the inhibitory action of serotonin on food intake. Eur J Neurosci. 2008;27(6):1400-8. https://doi.org/10.1111/j.14 60-9568.2008.06105.x 
38. Lira L, Almeida L, da Silva A, Cavalcante $T$, de Melo D, de Souza J, et al. Perinatal undernutrition increases meal size and neuronal activation of the nucleus of the solitary tract in response to feeding stimulation in adult rats. Int J Dev Neurosci. 2014;38:23-9. https://doi.org/10.1016/j.ijdevneu. 2014.07.007

39. Ferraz-Pereira $K$, da Silva Aragão $R$, Verdier $D$, Toscano A, Lacerda D, Manhães-de-Castro R, et al. Neonatal low-protein diet reduces the masticatory efficiency in rats. Br J Nutr. 2015;114(9):1515-30.

40. Carvalho-Santos J, Queirós-Santos A, Morais GL, Santana LH, Brito MG, Araújo RCS, et al. Efeito do tratamento com triptofano sobre parâmetros do comportamento alimentar em ratos adultos submetidos à desnutrição neonatal. Rev Nutr. 2010;23(4):503-11. https://doi.org/10.1590/S141 5-52732010000400001

41. Resnick O, Miller M, Forbes W, Hall R, Kemper T, Bronzino J, et al. Developmental protein malnutrition: Influences on the central nervous system of the rat. Neurosci Biobehav Rev. 1979;3(4):233-46.

42. Mathews T, Fedele D, Coppelli F, Avila A, Murphy $D$, Andrews A. Gene dose-dependent alterations in extraneuronal serotonin but not dopamine in mice with reduced serotonin transporter expression. J Neurosci Methods. 2004;140(1-2):169-81. https://doi.org/10.1016/j.jneumeth.2004.05.017

43. Holmes A, Murphy DL, Crawley JN. Evaluation of antidepressant-related behavioral responses in mice lacking the serotonin transporter.
Neuropsychopharmacology. 2002;27(6):914-23. https://doi.org/10.1016/S0893-133X(02)00374-3

44. Jennings $K$. Increased expression of the 5-ht transporter confers a low- anxiety phenotype linked to decreased 5-ht transmission. J Neurosci. 2006;26(35):8955-64. https://doi.org/10.1523/J NEUROSCI.5356-05.2006

45. Pringle A, Jennings $K$, Line $S$, Bannerman $D$, Higgs S, Sharp T. Mice overexpressing the 5-hydroxytryptamine transporter show no alterations in feeding behaviour and increased non-feeding responses to fenfluramine. Psychopharmacology. 2008;200(2):291-300. https:// doi.org/10.1007/s00213-008-1206-8

46. Silva CM, Gonçalves L, Manhaes-de-Castro R, Nogueira MI. Postnatal fluoxetine treatment affects the development of serotonergic neurons in rats. Neurosci Lett. 2010;483(3):179-83. https:// doi.org/10.1016/j.neulet.2010.08.003

47. Deiró T, Manhães-de-Castro R, Cabral-Filho J, Souza S, Freitas-Silva S, Ferreira L, et al. Neonatal administration of citalopram delays somatic maturation in rats. Braz J Med Biol Res. 2004;37(10):1503-9. https://doi.org/10.1590/S010 0-879X2004001000009

48. Grove KL, Smith MS. Ontogeny of the hypothalamic neuropeptide $Y$ system. Physiol Behav. 2003;79(1):47-63. https://doi.org/10.1016/S003 1-9384(03)00104-5

Received: August 8, 2016 Final version: March 27, 2017 Approved: May 5, 2017 